



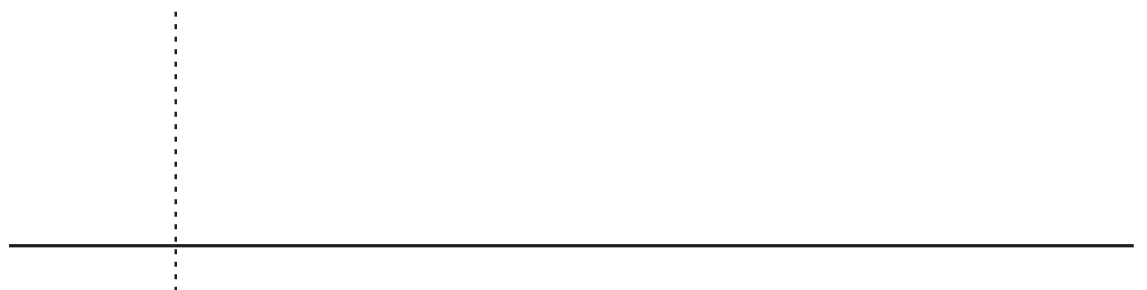

Epistemic Cultures 



\section{Epistemic Cultures}

How the Sciences Make

Knowledge 
Copyright (c) 1999 by the President and Fellows

of Harvard College

All rights reserved

Printed in the United States of America

Library of Congress Cataloging-in-Publication Data

Knorr Cetina, K. (Karin)

Epistemic cultures : how the sciences make knowledge / Karin Knorr Cetina.

p. $\mathrm{cm}$.

Includes bibliographical references and index.

ISBN 0-674-25893-2 (cloth : alk. paper). -

ISBN 0-674-25894-0 (pbk. : alk. paper)

1. Knowledge, Theory of. 2. Science-Philosophy.

3. Science-Social aspects. 4. Scientists-Interviews.

I. Title.

Q175.32.K45K57 1999

121—dc21 98-30277 
For Margarete Zetina 
